\title{
Combination of aloe-emodin with radiation enhances radiation effects and improves differentiation in human cervical cancer cells
}

\author{
JINGHUA LUO ${ }^{1,2}$, YONG YUAN ${ }^{3}$, PENGYU CHANG $^{1}$, DAWEI LI $^{4}$, ZHIQIANG LIU ${ }^{4}$ and YAQIN QU ${ }^{1}$ \\ ${ }^{1}$ Department of Radiotherapy, The First Hospital of Jilin University; ${ }^{2}$ Department of Radiotherapy, \\ The Jilin Hospital of Jilin University; ${ }^{3}$ Department of Gynecology, The Tumor Hospital of Jilin; ${ }^{4}$ Department of Neurology, \\ The First Hospital of Jilin University, Changchun, Jilin 130021, P.R. China
}

Received September 1, 2013; Accepted April 7, 2014

DOI: $10.3892 / \mathrm{mmr} .2014 .2318$

\begin{abstract}
The aim of the present study was to investigate the effects of aloe-emodin (AE) on the radiosensitivity and differentiation of HeLa human cervical cancer cells. Cell proliferation was assessed in the HeLa cervical cancer cell line by a methylthiazolyldiphenyl-tetrazolium bromide assay. Radiosensitivity was determined by a colony-forming assay. Flow cytometry was used for analysis of cell cycle distribution and apoptosis. The expression of $\gamma-\mathrm{H} 2 \mathrm{AX}$ and cyclin B was assessed by western blotting. Alkaline phosphatase (ALP) activity was measured by an ALP activity kit. It was demonstrated that $\mathrm{AE}$ inhibited the proliferation of HeLa cells in a concentration- and time-dependent manner, induced $\mathrm{G}_{2} / \mathrm{M}$ and $\mathrm{S}$ phase cell cycle arrest and enhanced the radiosensitivity of HeLa cells. The combination of $\mathrm{AE}$ and radiation induced apoptosis, upregulated cyclin B and $\gamma$-H2AX expression and further improved ALP activity compared with treatment with $\mathrm{AE}$ or radiation alone. AE enhanced the radiosensitivity of HeLa human cervical cancer cells in vitro, inhibited the proliferation of HeLa cells, induced $\mathrm{G}_{2} / \mathrm{M}$ phase cell cycle arrest and, in combination with radiation, induced the apoptosis and improved the differentiation of HeLa cells.
\end{abstract}

\section{Introduction}

Cervical cancer is the second most common type of malignancy in females, with over half a million cases occurring annually worldwide (1). Early stage cervical cancer can be treated with surgery or radiation with equivalent results. For locally advanced disease; however, radiation offers the only initial option for curative therapy (2). The dose of radiation is increased to enhance the effects of radiotherapy, which

Correspondence to: Professor Yaqin Qu, Department of Radiotherapy, The First Hospital of Jilin University, 71 Xinmin Street, Changchun, Jilin 130021, P.R. China

E-mail: qinyaqu@163.com

Key words: aloe-emodin, HeLa, G2/M arrest, radiosensitivity inhibits cervical cancer growth and development; however, this also leads to adverse reactions. In order to improve the local control and diminish side effects, radiation is combined with a radiosensitizer.

Aloe-emodin (AE), an Aloe vera leaf exudate (3), is used in traditional Chinese medicine for its laxative, antiviral and hepatoprotective properties (4-6). Its ingredients are of great value for the food, modern pharmaceutical and cosmetic industries (7). Previous studies have demonstrated that AE exerts anti-proliferative effects by inhibiting cell cycle progression in certain types of cancer cells, including cervical cancer (8), KB oral cancer cells (9), bladder cancer (10), leukemia (11), HK-2 human kidney cells (12) and nasopharyngeal carcinoma cells (13). AE is hypothesized to inhibit progression at the $\mathrm{G}_{2} / \mathrm{M}$ phase of the cell cycle. In addition, $\mathrm{AE}$ has been reported to inhibit the proliferation of gastric cancer and tongue squamous cancer cells by inhibiting the cell cycle at $S$ phase $(14,15)$.

Radiation affects the cell cycle, and radiosensitivity depends on the phase of the cell cycle and its progression (16), however, the effect of AE as a radiosensitizer in HeLa cells has not been reported. The present study hypothesized that the combination treatment of $\mathrm{AE}$ and radiation may enhance the radiosensitivity and differentiation of cervical cancer cells. In order to assess this hypothesis, the present study analyzed the effects of combination treatment with $\mathrm{AE}$ and radiation in the HeLa human cervical cancer cell line and examined the underlying mechanisms of the inhibition of HeLa cells.

\section{Materials and methods}

Cells and cell culture. The HeLa cell line was purchased from Jilin Tumor Institute (Changchun, China). Cells were cultured under a humidified atmosphere containing $5 \% \mathrm{CO}_{2}$ at $37^{\circ} \mathrm{C}$ in RPMI-1640 medium supplemented with $10 \%$ heat-inactivated fetal bovine serum, penicillin $(100 \mathrm{U} / \mathrm{ml})$ and streptomycin $(100 \mu \mathrm{g} / \mathrm{ml})$. Cells were subcultured every 2-3 days. Exponentially growing cells were used for the experiments.

Reagents and equipment. $\mathrm{AE}$ was purchased from Aladdin Chemical Co., Ltd. (Shanghai, China). RPMI-1640 medium (Gibco-BRL, Carlsbad, CA, USA), fetal bovine serum 
(FBS; Gibco-BRL), methylthiazolyldiphenyl-tetrazolium bromide (MTT; Sigma, St. Louis, MO, USA), enhanced chemiluminescence (ECL) substrate (Pierce Biotechnology, Inc., Rockford, IL, USA), mouse anti-human $\beta$-actin monoclonal antibody (Sigma), anti-cyclin B and anti- $\gamma$-H2AX monoclonal antibody (Abnova Corporation, Taipei, Taiwan), goat anti-mouse IgG/horseradish peroxidase (HRP; Beijing Dingguo Changsheng Biotechnology Co. Ltd, Beijing, China), electrophoresis system (Bio-Rad, Hercules, CA, USA), an alkaline phosphatase (ALP) activity assay kit (Nanjing Jiancheng Bioengineering Institute, Nanjing, China) and an X-ray linear accelerator (Varian Medical Systems, Palo Alto, CA, USA) were used in the present study. The dose rate was $200 \mathrm{c} \mathrm{Gy} / \mathrm{min}$ and the distance to the radiation source was $100 \mathrm{~cm}$.

MTT assay for cell proliferation. HeLa cells were seeded in 96-well plates at a density of $4.0 \times 10^{3}$ cells/well for $24 \mathrm{~h}$. The cells were treated with various concentrations of $\mathrm{AE}(0$, $5,10,25,50,75,100,200$ and $500 \mu \mathrm{M})$ for 24,48 and $72 \mathrm{~h}$. Dimethylsulfoxide (DMSO; $0.5 \%$ ) was used as the control. MTT $(5 \mathrm{mg} / \mathrm{ml})$ was added to each well and incubated for $4 \mathrm{~h}$ at $37^{\circ} \mathrm{C}$, following which DMSO was added to each well to dissolve the dark blue crystal product. The absorbance was measured at a wavelength of $590 \mathrm{~nm}$ using a microplate reader (Bio-Rad, Shanghai, China).

Colony-forming assays. A single-cell suspension was plated onto 6-well culture plates at different densities $\left(1 \times 10^{3}, 2 \times 10^{3}\right.$, $5 \times 10^{3}$ and $1 \times 10^{4}$ cells $/ \mathrm{ml}$ ). Following incubation for $24 \mathrm{~h}$, the cells were treated with $\mathrm{AE}$ in medium at different concentrations $(0,50,100$ and $200 \mu \mathrm{M})$ and cells were then exposed to different irradiation doses (0, 2, 4, 6, 8 and $10 \mathrm{~Gy})$. The cells were washed with normal medium and incubated in fresh, drug-free medium (10\% FBS in RPMI-1640) for 14 days, $24 \mathrm{~h}$ after radiation treatment. The cells were then washed with phosphate-buffered saline (PBS), fixed with methanol and stained with Giemsa solution. The number of colonies containing at least 50 cells was counted manually under a microscope (Olympus, Tokyo, Japan) by two independent investigators. The plating efficiency (PE) and survival fraction (SF) were calculated as follows: $\mathrm{PE}=$ colony-forming number / inoculating number $\times 100 . \mathrm{SF}=\mathrm{PE}$ (tested group) $/ \mathrm{PE}$ (control group) x 100. GraphPad Prism software 5.01 and the multi-target single-hit model (using the equation $\mathrm{SF}=1$ - $(1-$ $\left.e^{-\mathrm{D} / \mathrm{D} 0}\right)^{\mathrm{N}}$ were applied to generate the dose-survival curve and calculate the radiobiological parameters, including the mean lethal dose $\left(\mathrm{D}_{0}\right)$, quasi-threshold dose $\left(\mathrm{D}_{\mathrm{q}}\right)$, daily fraction dose of $2 \mathrm{~Gy}$ in clinical practice $\left(\mathrm{SF}_{2}\right)$, extrapolation number $(\mathrm{N})$, sensitizing enhancement ratio (SER) $\mathrm{D}_{0}$ and $\mathrm{SERD}_{\mathrm{q}}$. SER is one of the radiobiological parameters and $\mathrm{AE}$ increases the radiosensitivity in a concentration-dependent manner. Three replicates were set at each radiation dose.

Cell cycle distribution and apoptosis analysis by flow cytometry. Single-cell suspensions at a density of $1 \times 10^{6}$ cells/well were seeded in 6-well plates and incubated for $24 \mathrm{~h}$. The cells were treated with $\mathrm{AE}(0$ and $50 \mu \mathrm{M})$ for $30 \mathrm{~min}$, irradiated with doses of 0 and $4 \mathrm{~Gy}$ and incubated for 12,24,48 and $72 \mathrm{~h}$. The cells were harvested by trypsinization, washed twice with PBS

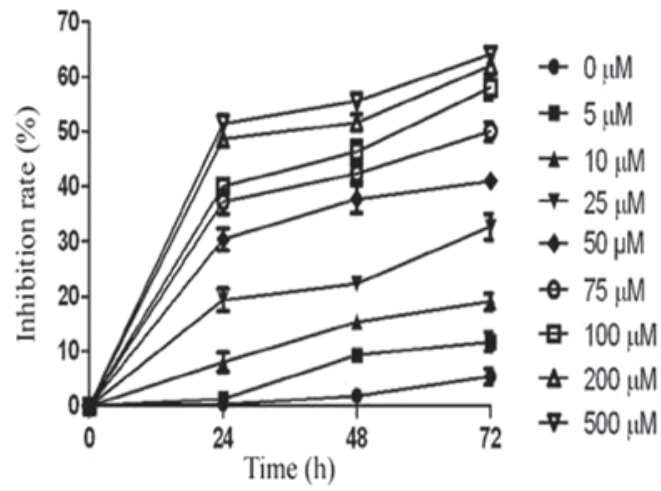

Figure 1. Proliferation of cells evaluated by methylthiazolyldiphenyl-tetrazolium bromide. HeLa cells were treated with different concentrations $(0$, $5,10,25,50,75,100,200$ and $500 \mu \mathrm{M}$ ) of aloe-emodin for 24, 48 and $72 \mathrm{~h}$. Dimethylsulfoxide solution served as a control. The mean \pm standard devaition of three independent experiments are shown $(\mathrm{P}<0.05)$.

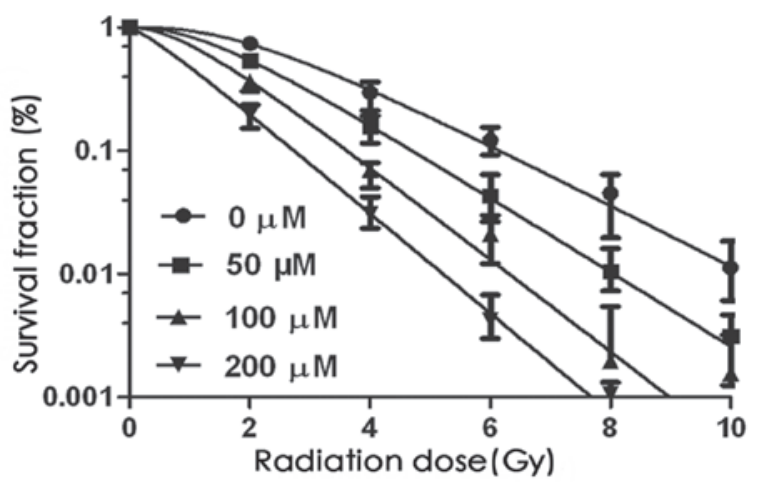

Figure 2. AE radiosensitivity measured by colony-forming assays. Dose-survival curve established by a colony-forming assay and analyzed by the multi-target single-hit model. HeLa cells were treated with aloe-emodin $(0,50,100$ and $200 \mu \mathrm{M})$ and radiation $(0,2,4,6,8$ and $10 \mathrm{~Gy})$. Experiments were repeated three times. The error bars represent standard error.

and sedimented by centrifugation at $1,500 \mathrm{x} g$ for $5 \mathrm{~min}$. The supernatant was removed and cells were fixed in $70 \%$ ice-cold ethanol overnight. Cells were washed twice with cold PBS, incubated with $20 \mu \mathrm{g} / \mathrm{ml} \mathrm{RNase}$ and stained with propidium iodide. Cell cycle distribution and apoptosis were determined by flow cytometry (FACSCalibur; BD Biosciences, Franklin Lakes, NJ, USA).

Western blot analysis of cyclin B and $\gamma-H 2 A X$ expression. A single-cell suspension was incubated for $24 \mathrm{~h}$, following which the cells were treated with $\mathrm{AE}(0$ and $50 \mu \mathrm{M})$ for $30 \mathrm{~min}$ followed by radiation treatment at doses of 0 and $4 \mathrm{~Gy}$. Subsequently, the cells were washed, scraped with ice-cold PBS and centrifuged. The cell lysate was harvested and protein concentration was determined with a protein assay kit (Ye zhou, Shanghai, China). A total of $50 \mu \mathrm{g}$ of protein was separated by sodium dodecyl sulfate-polyacrylamide gel electrophoresis, transferred onto nitrocellulose membranes (Mai bio, Shanghai, China) and inhibited overnight with PBS containing $3 \%$ skimmed milk. The membranes were incubated with primary antibodies against $\beta$-actin, cyclin $\mathrm{B}$ and $\gamma-\mathrm{H} 2 \mathrm{AX}$ for $2 \mathrm{~h}$ and washed with PBS. The membranes were then treated with HRP-conjugated rabbit anti-mouse IgG 
Table I. Radiobiological parameters of the dose-survival curve.

\begin{tabular}{|c|c|c|c|c|c|c|}
\hline Concentration & $\mathrm{D}_{0}$ & $\mathrm{D}_{\mathrm{q}}$ & $\mathrm{N}$ & $\mathrm{SF}_{2}$ & $\mathrm{SERD}_{0}$ & $\mathrm{SERD}_{\mathrm{q}}$ \\
\hline $0 \mu \mathrm{M}+\mathrm{RT}$ & 1.756 & 2.177 & 3.454 & 0.538 & & \\
\hline $50 \mu \mathrm{M}+\mathrm{RT}$ & 1.437 & 1.444 & 2.731 & 0.435 & 1.222 & 1.508 \\
\hline $100 \mu \mathrm{M}+\mathrm{RT}$ & 1.158 & 0.987 & 2.345 & 0.324 & 1.517 & 2.207 \\
\hline $200 \mu \mathrm{M}+\mathrm{RT}$ & 1.072 & 0.283 & 1.302 & 0.286 & 1.638 & 7.695 \\
\hline
\end{tabular}

Radiobiological parameters of the dose-survival curve. RT, radiation dose $4 \mathrm{~Gy} ; \mathrm{D}_{0}$, mean lethal dose; $\mathrm{D}_{\mathrm{q}}$, quasi-threshold dose; $\mathrm{SF}_{2}$, daily fraction dose of $2 \mathrm{~Gy}$ in clinical practice; $\mathrm{N}$, extrapolation number; SER, sensitizing enhancement ratios. $\mathrm{SERD}_{0}=\mathrm{D}_{0}$ control group $/ \mathrm{D}_{0} \mathrm{AE}$ group; $\mathrm{SERD}_{\mathrm{q}}=\mathrm{D}_{\mathrm{q}}$ control group / $\mathrm{D}_{\mathrm{q}} \mathrm{AE}$ group.
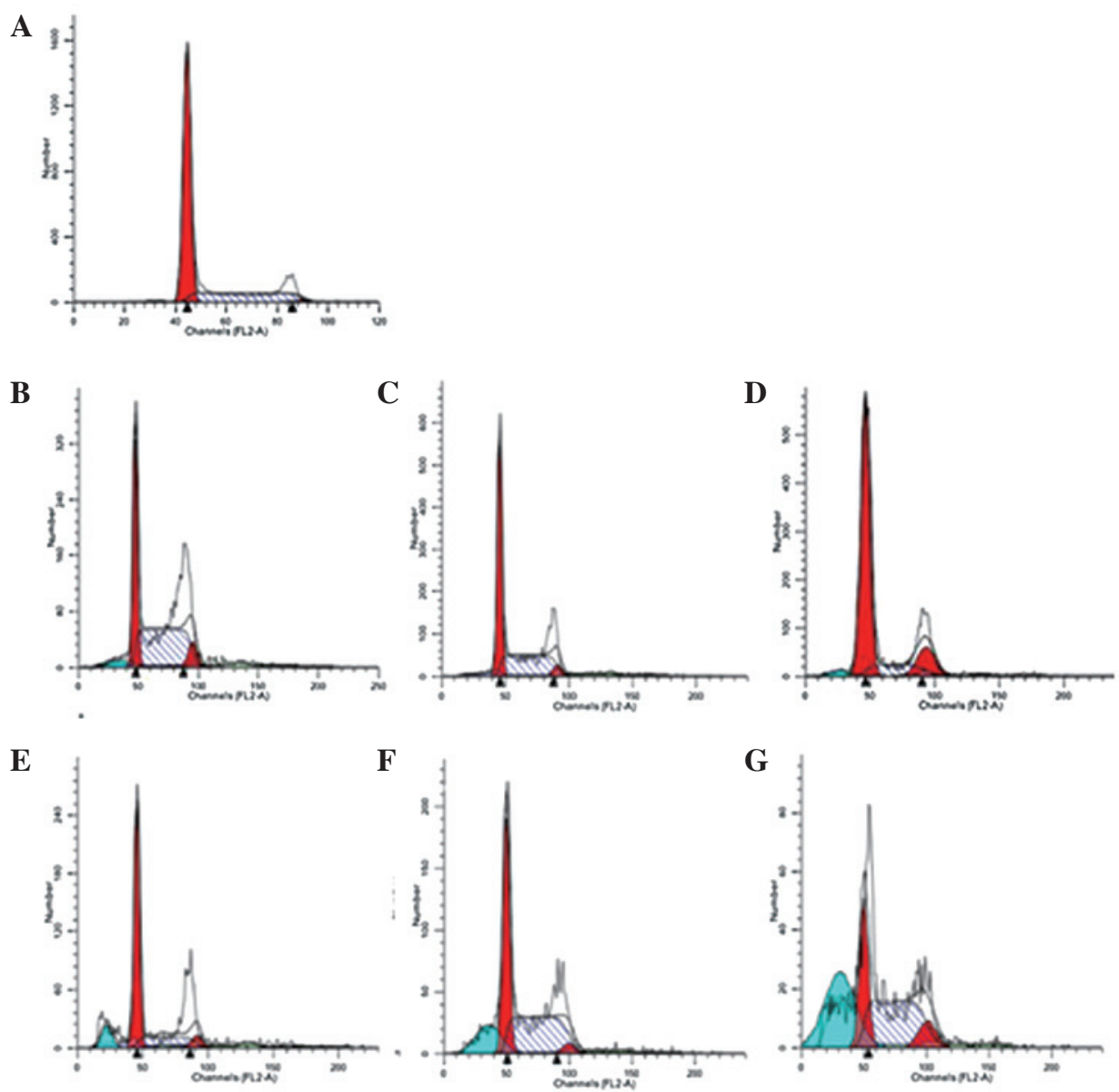

Figure 3. Cell cycle distribution by flow cytometry. (A) Control (dimethylsulfoxide) at $12 \mathrm{~h}$; (B) AE (50 $\mu \mathrm{M})$ treatment at $12 \mathrm{~h}$; (C) irradiation (4 Gy) at $12 \mathrm{~h}$; (D-G) combination treatment with $\mathrm{AE}(50 \mu \mathrm{M})$ and irradiation (4 Gy) at 12, 24, 48 and $72 \mathrm{~h}$, respectively. AE, aloe-emodin.

secondary antibody. Antibody-reactive bands were visualized by the ECL detection system (Amersham Pharmacia Biotech, Piscataway, NJ, USA). Representative data were from an individual experiment repeated three times.

Determination of relative ALP activity. A single-cell suspension was incubated for $24 \mathrm{~h}$, following which the cells were treated with $\mathrm{AE}(0$ and $50 \mu \mathrm{M})$ for $30 \mathrm{~min}$ followed by radiation treatment at doses of 0 and 4 Gy. Subsequently, the cells were cultured for 24,48 and $72 \mathrm{~h}$. The cells were washed, lysed and centrifuged. The supernatant was used for the measurement of ALP activity with an ALP activity assay kit (Nanjing Jiancheng Bioengineering Institute). The absorbance at $520 \mathrm{~nm}$ was measured on a microplate reader. Three independent experiments were performed in this analysis.

Statistical analysis. Statistical analysis was performed using SPSS version 18.0 (SPSS, Inc., Chicago, IL, USA). Student's t-test or one-way analysis of variance were used for all comparisons. Data are presented as the mean \pm standard error of three independent experiments. $\mathrm{P}<0.05$ was considered to indicate a statistically significant difference. 


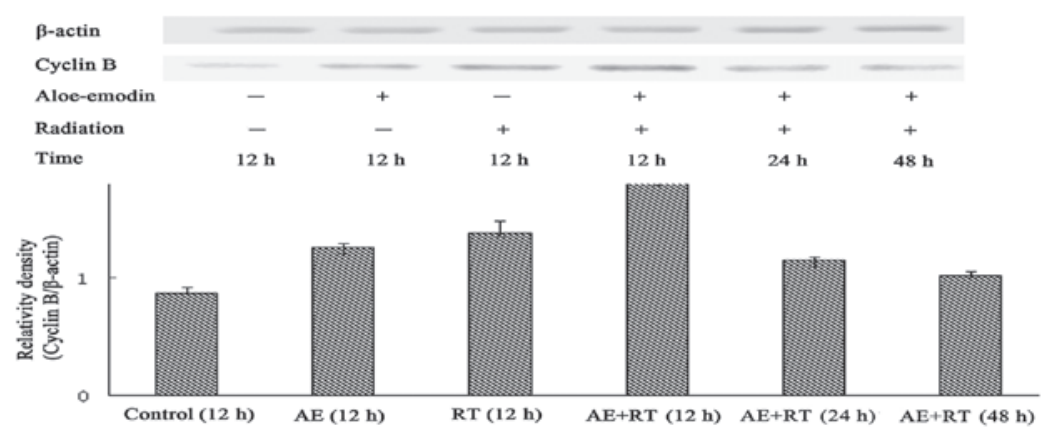

Figure 4. Cyclin B expression by western blotting. Control (dimethylsulfoxide) at $12 \mathrm{~h}$; AE $(50 \mu \mathrm{M})$ treatment at $12 \mathrm{~h}$; irradiation (4 Gy) at $12 \mathrm{~h}$; combination treatment with $\mathrm{AE}(50 \mu \mathrm{M})$ and irradiation ( $4 \mathrm{~Gy})$ at 12, 24 and $48 \mathrm{~h}$, respectively. Band intensity was analyzed by densitometry and the results are expressed as the ratio of the densitometry value of the treated group to that of the control group $(\mathrm{P}<0.05)$. AE, aloe-emodin; RT, radiation dose $4 \mathrm{~Gy}$.

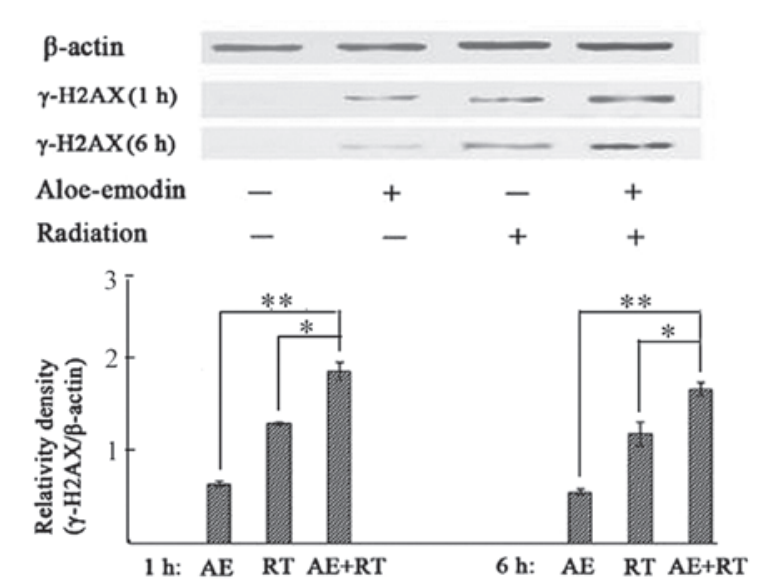

Figure 5. $\gamma$-H2AX expression by western blotting. Control (dimethylsulfoxide); treated with $\mathrm{AE}(50 \mu \mathrm{M})$ or radiation $(4 \mathrm{~Gy})$ alone and $\mathrm{AE}(50 \mu \mathrm{M})$ plus radiation (4 Gy), at 1 or $6 \mathrm{~h}$ following treatment. Band intensity was analyzed by densitometry and the data are presented as the mean \pm standard deviation of three independent experiments. ${ }^{*} \mathrm{P}<0.05$ or ${ }^{* * *} \mathrm{P}<0.01$.

\section{Results}

Growth inhibitory effects of AE on HeLa cells. The effect of AE on the proliferation of HeLa cells was evaluated by an MTT assay (Fig. 1). AE inhibited the proliferation of HeLa cells in a concentration- and time-dependent manner, particularly when the concentration of $\mathrm{AE}$ was $>50 \mu \mathrm{M}$. Based on these results, $50 \mu \mathrm{M} \mathrm{AE}$ was selected as the dose for subsequent experiments.

Effect of AE on the radiosensitization of HeLa cells. As shown in Fig. 2 and Table I, the radiobiological parameters $\mathrm{D}_{0}, \mathrm{D}_{\mathrm{q}}, \mathrm{N}$ and $\mathrm{SF}_{2}$ decreased, and the $\mathrm{SERD}_{0}$ and $\mathrm{SERD}_{\mathrm{q}}$ increased in response to $\mathrm{AE}$ in a concentration-dependent manner in vitro. These effects were enhanced by combination treatment compared with the effect of radiation alone.

Effects of AE and radiation on HeLa cell cycle distribution and apoptosis assessed by flow cytometry. As shown in Fig. 3, $\mathrm{HeLa}$ cells treated with radiation or $\mathrm{AE}$ alone and the combination of radiation with $\mathrm{AE}$ demonstrated an increase in the number of cells in the $\mathrm{G}_{2} / \mathrm{M}$ phase. Investigation demonstrated that the S phase was increased with AE alone at 48 and $72 \mathrm{~h}$ and a sub- $\mathrm{G}_{1}$ peak clearly appeared (apoptosis) at 24,48 and

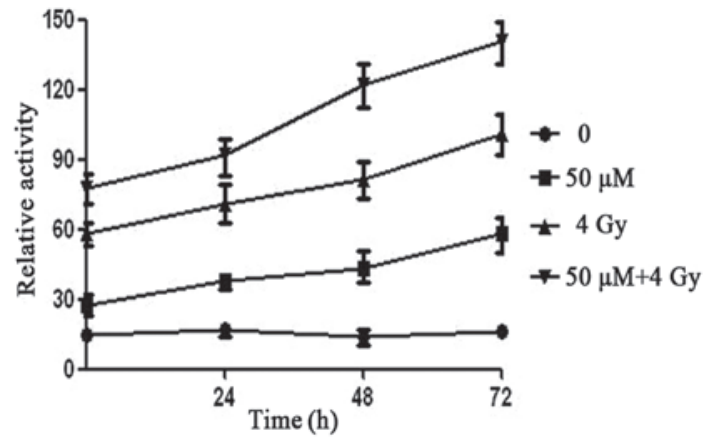

Figure 6. Alkaline phosphatase activity investigation by kits. HeLa cells were treated with dimethylsulfoxide, $\mathrm{AE}(50 \mu \mathrm{M})$ or radiation (4 Gy) alone and AE plus radiation for 24, 48 and $72 \mathrm{~h}$. All the values are expressed as the means \pm standard deviation of three independent experiments. AE, aloe-emodin.

$72 \mathrm{~h}$ in cells treated with the combination of radiation and AE. Apoptotic peaks were significant with the extension of time.

Cyclin B and $\gamma-H 2 A X$ expression by western blotting. Figs. 4 and 5 show the expression of cyclin B and $\gamma-\mathrm{H} 2 \mathrm{AX}$ by western blotting. The cells treated with radiation (4 Gy) or $\mathrm{AE}(50 \mu \mathrm{M})$ alone and a combination of radiation and $\mathrm{AE}$ expressed cyclin B and $\gamma-\mathrm{H} 2 \mathrm{AX}$. The expression of cyclin B was highest at $12 \mathrm{~h}$ in cells treated with the combination and the expression of $\gamma-\mathrm{H} 2 \mathrm{AX}$ in the combination group was higher than that following $\mathrm{AE}$ or radiation treatment alone.

Relative activity of ALP. As shown in Fig. 6, the ALP activity of HeLa cells was increased by the treatment with radiation or $\mathrm{AE}$ alone and the combination of radiation and $\mathrm{AE}$ in a time-dependent manner. This effect was enhanced by combination treatment compared with the effect of radiation or $\mathrm{AE}$ alone.

\section{Discussion}

Although the anticancer effect of AE has been reported in numerous studies, its effect on enhancing the radiosensitivity of cancer cells has not been investigated to date. The present study investigated the effect of AE on the radiosensitivity and differentiation of HeLa cells in vitro and examined its underlying mechanisms. 
The results demonstrated that AE inhibited the proliferation of HeLa cells in vitro in a concentration- and time-dependent manner. Notably, AE concentrations $>50 \mu \mathrm{M}$ demonstrated significant cytotoxicity in the MTT assay. The radiosensitivity of cells treated with AE increased in a dose-dependent manner compared with that of cells treated without AE in colony-forming assays. These results demonstrated that $\mathrm{AE}$ enhanced the radiosensitivity of HeLa cells. It has been reported that the $G_{2} / M$ and $M$ phases are the most sensitive to radiation in the cell cycle (17-19). Flow cytometry results demonstrated that treatment with $\mathrm{AE}$ or radiation alone and $\mathrm{AE}$ in combination with radiation inhibited cell cycle progression at the $\mathrm{G}_{2} / \mathrm{M}$ phase. Furthermore, the experiments also demonstrated that the cells arrested in the $S$ phase with AE alone at 48 and $72 \mathrm{~h}$ and that there was a sub- $\mathrm{G}_{1}$ peak at 24,48 and $72 \mathrm{~h}$, which was particularly clear $72 \mathrm{~h}$ after combination treatment with $\mathrm{AE}$ and radiation in a concentration-dependent manner. The underlying mechanism of apoptosis (sub- $\mathrm{G}_{1}$ peak) in HeLa cells caused by $\mathrm{S}$ phase arrest was not further investigated in the present study. However, previous studies have demonstrated that $\mathrm{AE}$ is able to inhibit the growth of gastric cancer cells and induce apoptosis in squamous cell carcinoma of the tongue by inhibiting cell cycle progression at the $\mathrm{S}$ phase $(14,15)$. The findings of the present study therefore, support the results of the contribution of $S$ phase arrest to apoptosis. The present study hypothesized that $\mathrm{S}$ phase arrest may be one of the factors triggering apoptosis in HeLa cells, although it may not be the only one.

The cell cycle is a strictly ordered process that is controlled by multiple cell cycle regulatory proteins, including cyclin and cyclin dependent kinase (CDK) protein kinases. The main cell cycle regulatory proteins that control the $\mathrm{G}_{2} / \mathrm{M}$ phase are known as cyclin B and CDK1. The levels of CDK1 remain relatively constant during the cell cycle, while the levels of cyclin B undergo cyclical changes. Cyclin B is synthesized at late $G_{1}$ phase and its expression levels increase as the cycle progresses, reaching a maximum value at the $\mathrm{G}_{2}$ phase. As cyclin $\mathrm{B}$ accumulates, the activity of CDK1 kinase is observed and reaches a maximum value at $G_{2}$ phase, which is maintained throughout the $\mathrm{M}$ phase. Cyclin $\mathrm{B}$ is rapidly degraded at late $\mathrm{M}$ phase, concomitant with the inactivation of CDK1, and the cell enters the next cycle $(20,21)$. CDK1 regulates the cell cycle by modulating the expression of cyclin B. Therefore, cyclin B was selected for analysis in the present study. Western blot analysis demonstrated that cyclin B expression was upregulated in cells treated with AE or radiation alone. Furthermore, combination treatment with $\mathrm{AE}$ and radiation further promoted cyclin $\mathrm{B}$ expression at $12 \mathrm{~h}$. This result was in line with the flow cytometry results. AE in combination with radiation-arrested cells in the G2/M phase, inhibited cells with injured DNA entering into the $\mathrm{M}$ phase and dividing, thus reducing tumor cell survival and enhancing cell radiosensitivity.

DNA double strand breaks (DSBs) are the most important biological effects of radiation. The histone protein $\mathrm{H} 2 \mathrm{AX}$ is a key protein involved in the repair of DNA DSBs, which is a member of the H2A histone family (22). H2AX is rapidly phosphorylated on serine 4 residues at the carboxyl terminus to form $\mathrm{rH} 2 \mathrm{AX}$ at burgeoning DSB sites $(23,24)$, which is responsible for the recruitment of DNA repair proteins, including BRCA1, 53bp1 and Nbs1-Mre11-Rad50, to the sites of DNA damage (25-27). Immediately following the formation of DSBs, large numbers of $\mathrm{rH} 2 \mathrm{AX}$ molecules accumulate around the break sites $(23,24)$. rH2AX detection has the potential to function as a diagnostic tool and an indicator of treatment efficacy (23). Similarly previous studies have demonstrated that YY1 and certain genes, including RBL2, E2F2, CDK6 and CCNE1 may be potential targets for cervical cancer detection, monitoring and therapy $(28,29)$. Western blot analysis demonstrated that $\gamma-\mathrm{H} 2 \mathrm{AX}$ is expressed in cells treated with AE or radiation alone. Furthermore, combination treatment with $\mathrm{AE}$ and radiation further upregulated $\gamma$-H2AX expression at 1 and $6 \mathrm{~h}$, indicating the further increase of DSBs. Histone H2AX phosphorylation is crucial in apoptosis and the appearance of strong H2AX phosphorylation is concurrent with the initiation of DNA fragmentation (30). Flow cytometry also demonstrated sub-G1 peaks (apoptosis) at 24, 48 or $72 \mathrm{~h}$.

Cellular ALP is increasingly recognized as an important marker for monitoring tumor cell differentiation (31-33). AE inhibited the growth of cervical cancer cells, KB oral cancer cells and gastric cancer cells by inducing cancer cell differentiation $(8,9,14)$. The present study demonstrated that the activity of ALP in HeLa cells is increased by treatment with radiation or $\mathrm{AE}$ alone and further increased by a combination of radiation and $\mathrm{AE}$ in a time-dependent manner. The differentiation of HeLa cells may also be improved by combination treatment with radiation and $\mathrm{AE}$ compared with the treatment with radiation or AE alone.

An ideal radiosensitizer enhances the radiosensitivity of tumor cells and is harmless to or protects normal tissue. Previous studies demonstrated that AE has no toxic effects on normal cells (34). However, whether or not it protects normal tissue remains to be determined.

The present findings, together with those of previous studies, suggest that $\mathrm{AE}$ has the following antitumor effects: i) $\mathrm{AE}$ inhibits the growth of HeLa cells; ii) AE arrests HeLa cells at the $S$ and $G_{2} / M$ phases, inducing tumor cell apoptosis; iii) $\mathrm{AE}$ increases the radiation sensitivity of HeLa cells by inducing $\mathrm{G}_{2} / \mathrm{M}$ phase arrest; iv) AE increases radiation-induced DNA damage; and v) the combination of radiation and AE further improves the differentiation of HeLa cells. The present results are consistent with the hypothesis that combination treatment with AE enhances the effects of radiotherapy on HeLa cells in vitro. The exposure of cells to the combination of two cytotoxic modalities, AE and radiation, demonstrated an increase in the cell death of HeLa cells. This indicated that AE may be an effective radiosensitizer and a potential therapeutic agent for the inhibition of tumor cell proliferation. Further in vivo studies are required to clarify the anticancer effect of $\mathrm{AE}$ and its mechanisms with the intention of clinical application.

\section{References}

1. Shepherd JH: Cervical cancer. Best Pract Res Clin Obstet Gynaecol 26: 293-309, 2012.

2. Yashar CM, Spanos WJ, Taylor DD and Gercel-Taylor C: Potentiation of the radiation effect with genistein in cervical cancer cells. Gynecol Oncol 99: 199-205, 2005.

3. Dutta A, Bandyopadhyay S, Mandal C and Chatterjee M: Aloe vera leaf exudate induces a caspase-independent cell death in Leishmania donovani promastigotes. J Med Microbiol 56: 629-636, 2007.

4. Krumbiegel G and Schulz HU: Rhein and aloe-emodin kinetics from senna laxatives in man. Pharmacology 47: 120-124, 1993. 
5. Andersen DO, Weber ND, Wood SG, Hughes BG, Murray BK and North JA: In vitro virucidal activity of selected anthraquinones and anthraquinone derivatives. Antiviral Res 16: 185-196, 1991.

6. Arosio B, Gagliano N, Fusaro LM, Parmeggiani L, Tagliabue J, Galetti P, De Castri D, Moscheni C and Annoni G: Aloe-Emodin quinone pretreatment reduces acute liver injury induced by carbon tetrachloride. Pharmacol Toxicol 87: 229-233, 2000.

7. Eshun K and He Q: Aloe vera: a valuable ingredient for the food, pharmaceutical and cosmetic industries - a review. Crit Rev Food Sci Nutr 44: 91-96, 2004.

8. Guo JM, Xiao BX, Liu Q, Zhang S, Liu DH and Gong ZH: Anticancer effect of aloe-emodin on cervical cancer cells involves $\mathrm{G} 2 / \mathrm{M}$ arrest and induction of differentiation. Acta Pharmacol Sin 28: 1991-1995, 2007.

9. Xiao B, Guo J, Liu D and Zhang S: Aloe-emodin induces in vitro $\mathrm{G} 2 / \mathrm{M}$ arrest and alkaline phosphatase activation in human oral cancer KB cells. Oral Oncol 43: 905-910, 2007.

10. Lin JG, Chen GW, Li TM, Chouh ST, Tan TW and Chung JG: Aloe-emodin induces apoptosis in T24 human bladder cancer cells through the p53 dependent apoptotic pathway. J Urol 175: 343-347, 2006.

11. Chen HC, Hsieh WT, Chang WC and Chung JG: Aloe-emodin induced in vitro $\mathrm{G} 2 / \mathrm{M}$ arrest of cell cycle in human promyelocytic leukemia HL-60 cells. Food Chem Toxicol 42: 1251-1257, 2004

12. Suboj P, Babykutty S, Srinivas P and Gopala S: Aloe emodin induces $\mathrm{G} 2 / \mathrm{M}$ cell cycle arrest and apoptosis via activation of caspase-6 in human colon cancer cells. Pharmacology 89: 91-98, 2012.

13. Lin ML, Lu YC, Chung JG, Li YC, Wang SG, N G SH, Wu CY, $\mathrm{Su} \mathrm{HL}$ and Chen SS: Aloe-emodin induces apoptosis of human nasopharyngeal carcinoma cells via caspase-8-mediated activation of the mitochondrial death pathway. Cancer Lett 291 : $46-58,2010$.

14. Guo J, Xiao B, Zhang S, Liu D, Liao Y and Sun Q: Growth inhibitory effects of gastric cancer cells with an increase in $\mathrm{S}$ phase and alkaline phosphatese activity repression by aloe-emodin. Cancer Biol Ther 6: 85-88, 2007.

15. Chiu TH, Lai WW, Hsia TC, et al: Aloe-emodin induces cell death through $\mathrm{S}$-phase arrest and caspase-dependent pathways in human tongue squamous cancer SCC-4 Cells. Anticancer Res 29: 4503-4511, 2009.

16. Pawlik TM and Keyomarsi K: Role of the cell cycle in mediating sensitivity to radiotherapy. Int J Radiat Oncol Biol Phys 59: 928-942, 2004

17. Terasima T and Tolmach LJ: X-ray sensitivity and DNA synthesis in synchronous populations of HeLa cells. Science 140: 490-492, 1963.

18. Sinclair WK and Morton RA: X-ray sensitivity during the cell generation cycle of cultured Chinese hamster cells. Radiat Res 29: 450-474, 1966.

19. Sinclair WK: Cyclic x-ray responses in mammalian cells in vitro. Radiat Res 33: 620-643, 1968.
20. Chu HL, Mao H, Feng W, Liu JW and Geng Y: Effects of sulfated polysaccharide from Masson pine (Pinus massoniana) pollen on the proliferation and cell cycle of HepG2 cells. Int J Biol Macromol 55: 104-108, 2013.

21. Westendorf JM, Swenson KI and Ruderman JV: The role of cyclin B in meiosis I. J Cell Biol 108: 1431-1444, 1989.

22. West $\mathrm{MH}$ and Bonner WM: Histone $2 \mathrm{~A}$, a heteromorphous family of eight protein species. Biochemistry 19: 3238-3245, 1980.

23. Bonner WM, Redon CE, Dickey JS, Nakamura AJ, Sedelnikova OA, Solier S and Pommier Y: Gamma H2AX and cancer. Nat Rev Cancer 8: 957-967, 2008.

24. Rogakou EP, Boon C, Redon C and Bonner WM: Megabase chromatin domains involved in DNA double-strand breaks in vivo. J Cell Biol 146: 905-916, 1999.

25. Sedelnikova OA, Pilch DR, Redon C and Bonner WM: Histone $\mathrm{H} 2 \mathrm{AX}$ in DNA damage and repair. Cancer Biol Ther 2: 233-235, 2003.

26. Celeste A, Fernandez-Capetillo O, Kruhlak MJ, Pilch DR, Staudt DW, Lee A, Bonner RF, Bonner WM and Nussenzweig A: Histone H2AX phosphorylation is dispensable for the initial recognition of DNA breaks. Nat Cell Biol 5: 675-679, 2003.

27. Ward IM, Minn K, Jorda KG and Chen J: Accumulation of checkpoint protein 53BP1 at DNA breaks involves its binding to phosphorylated histone H2AX. J Biol Chem. 278: 19579-19582, 2003.

28. Baritaki S, Sifakis S, Huerta-Yepez S, et al: Overexpression of VEGF and TGF-beta1 mRNA in Pap smears correlates with progression of cervical intraepithelial neoplasia to cancer: implication of YY1 in cervical tumorigenesis and HPV infection. Int J Oncol 31: 69-79, 2007.

29. Arvanitis DA and Spandidos DA: Deregulation of the G1/S phase transition in cancer and squamous intraepithelial lesions of the uterine cervix: a case control study. Oncol Rep 20: 751-760, 2008.

30. Rudel T and Bokoch GM: Membrane and morphological changes in apoptotic cells regulated by caspase-mediated activation of PAK2. Science 276: 1571-1574, 1997.

31. Xiao B, Guo J, Lou Y, Meng D, Zhao W, Zhang L, Yan C and Wang D: Inhibition of growth and increase of alkaline phosphatase activity in cultured human oral cancer cells by all-trans retinoic acid. Int J Oral Maxillofac Surg 35: 643-648, 2006.

32. Dabare AA, Nouri AM, Cannell H, Moss T, Nigam AK and Oliver RT: Profile of placental alkaline phosphatase expression in human malignancies: effect of tumour cell activation on alkaline phosphatase expression. Urol Int 63: 168-174, 1999.

33. Leng B, Liu XD and Chen QX: Inhibitory effects of anticancer peptide from Mercenaria on the BGC-823 cells and several enzymes. FEBS Lett 579: 1187-1190, 2005.

34. Pecere T, Gazzola MV, Mucignat C, Parolin C, Vecchia FD, Cavaggioni A, Basso G, Diaspro A, Salvato B, Carli M and Palù G: Aloe-emodin is a new type of anticancer agent with selective activity against neuroectodermal tumors. Cancer Res 60: 2800-2804, 2000. 